\title{
Food Insecurity and Indian Muslims
}

\author{
Md. Ismail \& Dr Md. Mustaquim \\ Research Scholar, Department of Geography, Aliah University, Kolkata-700 091 \\ Assistant Professor, Department of Geography, Aliah University, Kolkata-700 091,
}

\begin{abstract}
Food insecurity is one of the burning issues in the world in general and in the developing, and under developed countries in particular. Food insecurity explained a situation when people fail to manage minimum amount of food for active and healthy living. The status of food insecurity measures on the basis of various dimensions and it may be measures at household level, individual level and community level. The present paper attempts to measures the status of food insecurity among Muslim households because Muslim is one of the important and most vulnerable communities in India. The entire study is based upon the primary data. More than 63 per cent Muslim households are food insecure in the study area. The paper tries to find out the relation between food insecurity and its determiners.
\end{abstract}

Keywords: Food insecurity, Muslim, education, occupation, family size, income, landholding

\section{Introduction}

Food insecurity is a situation in which individuals have neither physical nor economic access to the nourishment they need (Reutlinger, 1987). Food insecurity refers to situation when people do not get sufficient amount of food and go to bed with hungry. Yet, there are 828 million people suffering from hunger and starvation, only 13 per cent people are in the developed world and rest 87 per cent in the developing world. Food insecurity "Did not have access at all times to enough food for an active and healthy life"...with no need for recourse to emergency food sources or other extraordinary coping behaviors to meet their basic food needs. A household is said to be food insecure when its consumption falls to less than 80 per cent of the daily Minimum Recommended Allowance (MRA) of caloric intake for an individual to be active and healthy (ICMR 2400 caloric food secure). Based on temporal dimension, two types of household food insecurity can be distinguished: chronic and transitory. Chronic (permanent) food insecurity refers to a continuously inadequate diet resulting from lack of resources to produce or acquire food (Reutlinger 1987). Transitory food insecurity refers to a temporary decline in the households' access to enough food. Though India is achieved self sufficiency by increasing its food production due to the development of agricultural system. Still, in India, large numbers of people do not get two square meals and go to the bed hungry. About 26 per cent population is still suffering from the hungry and starvation and its related diseases in our country. In this context, researchers try to analyze the picture of food insecurity among Muslims in the study area, because Muslims are the most vulnerable community not only in study area but also all over world.

\section{Review of Literature}

It is very difficult work to review the vast literature existing on Household Food and Nutrition Security and its various related aspects. However, a modest attempt has been made in this regard. In Indian context; the issue of food security is poorly understood and analyzed focusing mainly on the spatial distribution of food availability but three other important components of food security i.e. food stability, accessibility and utilization have been ignored. One thing very important to note that very little work has been done on household food security in India at micro level

Mohammad A (1989) analyzed the food production and food problem in India. He attempted a state level analysis of trends in area, production, yield of food grain crops, supply and demand for food grains, food availability, and surplus and deficit situations in the country and suggested various strategies of achieving food security. Priyadarshini (2006) pointed out that Food Security does not mean only the availability of adequate food but also other dimensions notably the issues like nutrition, health, education economic access to nutritious food and safe drinking water and livelihood security. Rajmani Singh (2006) discussed the growth of population, pattern of land utilization, production of crops and food security in Manipur. Utpal Kumar Das (2006) examined the problem of Food Security in case of the state of Tripura vis-àvis to that of India. R.P. Bhattacharjee (2006) studied the problems and prospects of PDS in Arunachal Pradesh. Banerjee (1997) examined the population explosion, food security and sustainable development. Bhagat (2000) examined the population growth; poverty and food grains supply in India and also pointed out the trends and future prospect. Dutta and Ramaswami (2001) focused exclusively on the public 
distribution system(PDS) of food-grains with respect to variations in the patterns of utilization; degree of success in targeting in the two states, estimates of the implicit subsides by expenditure groups and the cost of providing a rupee of income support of a target group (Dutta and Ramaswami ).Swaminathan (2001) suggested achieving sustainable livelihood and freedom from hunger through 'Community Grain Bank' which should be established at village level, where there is acute problems of hunger.

\section{Objectives of the study \\ - $\quad$ To measures the households' food insecurity status of Muslim. \\ - To identify the underlying causes of the food insecurity among the Muslims' households. \\ - To examine the relationship among the various determents of food insecurity in the sample area.}

\section{Database and Methodology}

The present study is entirely based on primary data and sample households drawn from the nine Muslim dominated villages of Harishchandrapur block 2 in Malda district of West Bengal. The relevant data were collected through a primary survey, by visiting the households with a suitable questionnaire. The opportunities given by meeting the households in person provides a great scope for an in depth investigation. All the data were converted into relative number such as percentage and ratio methods used for observed the overall situation of the villages. Study is based on the basis of five indicators, employment structure, landownership, education levels, size of family and per capita income. The sampling has been collected from nine villages on the basic of size of population and one village has been taken from each Gram Panchayat. Three villages have been taken which having less than 2,000 populations and 45 sampling household has been considered for three villages. Three medium sizes of villages taken for sampling which having population between 2000- 4000 and 60 households have been taken from selected three villages. Lastly, 66 households have been taken from three large size villages which having population more than 4000 .

\section{Study area}

Malda was the Capital of Gour-Banga and Now the gate way of North Bengal located between latitudes $24^{\circ} 40^{\prime} 20^{\prime} \mathrm{N}$ to $25^{\circ} 32^{\prime} 8^{\prime \prime} \mathrm{N}$, and longitudes $87045^{\prime} 50 \mathrm{E}$ to $88028^{\prime} 10^{\prime \prime} \mathrm{E}$. Harishchandrapur is located away from the $70 \mathrm{~km}$ from the Malda town. The block Harischandrapur-2 with an area of $217.22 \mathrm{Sq}$. km. hectares represents the fertile agriculture. Total population of the block Harischandrapur-2 is 1, 98,127 (with Male 1, 02,075 and Female 96,052).The area is dominated by sandy soil, which is most fertile and productive for agricultural crops and vegetables. Climatic condition of the study is hot and humid, which is highly favorable for agriculture. The temperature of the study area varies from $24^{\circ} \mathrm{C}$ to $40^{\circ} \mathrm{C}$ in summer season and $10^{\circ} \mathrm{C}$ to $24^{\circ}$ $\mathrm{C}$ in winter season. The monsoon extends from the months of June to September, and gives heavy rainfall every year. Annual average rainfall is around 175 centimeters, which is most suitable for rice cultivation. Nearly twothird of the total land area of the study area is used for cultivation and more than 80 per cent of the total populations of the study area are engaged in agriculture sector.

\section{Status of Food Insecurity among Muslim Households in Harishchandrapur 2 Block Size of Family and Food Insecurity}

Size of family and types of family are close relationship. Number of family members are the important indicators for measures the level of socio- economic status of population. Total income of households and production of food grain both are divided by the family members. Numbers of mouth in households means low level of food intake. According to primary survey, more than 38.71 per cent households in the sampling study are food insecure which having less than 5 members in family (Table1). About 56.14 per cent food insecure households found among the group of 5-10 members in family and more than 77 per cent insecure population found among the group of large family which have more than 10 members in family.

\section{Land Holding Size and Household Food Insecurity among Muslims}

Ownership of land and size of landholding are very important determiner to study socioeconomic status of rural areas in any region. There is very close relationship between size of land holding and food insecurity (Table2). The per capita availability of land in rural areas specially the areas of agro based economy is identical factors for knowing the status of household's food insecurity. Different study by various scholars showed that availability of land per capita income and size of land holding reduced the level of poverty, hunger and food insecurity status of population. Ownership of land not only produced food corps, it also provide self employment opportunities of the households member and decreasing pressure of unemployment. On the basis of primary survey, more than 77 per cent food insecure is lies among the landless householders, their occupation mainly related to primary activities. About 74.42 per cent food insecure households found among the 
groups, having less than 5 bigha land which is very small size of holding. Another lager number 41.18 per cent of insecure household found among the group, they have land between 6 bigha to 10 bigha. Nearly 38.10 per cent food insecure households found in the group having their land in between 11- 15 bigha followed by 22.22 per cent among the group of 16-20 bigha landholders and 28.57 per cent food insecure households found among the group they have more than 20 bigha land. Except the group of above 20 bigha, in case of all the groups, food insecurity status improves due to the increasing of ownership of land in the study areas.

\section{Food Insecurity and Occupational Structure among the Muslims}

Occupational structure and food insecurity status of households are closely related to each other. Occupational structure is the important indicator which measures the level of insecurity status (Table3). On the basis of occupational structures of food insecurity varies from one occupation to another occupation because occupation is also the important determinant for per capita income of population. According to study, food insecurity varies from occupation to occupation. Maximum numbers of food insecure households are found among the agricultural labourer, it is nearly 88 per cent of the total agricultural labourer of households another large number of insecure households found among the other workers ( 78.57 per cent), followed by farmer also the very low paid economic activities in modern societies. Among the farmer, more than 72 per cent households found insecure in terms of caloric intake. Daily labourer shows comparatively meager low insecure households which are 66.67 per cent of the total daily labourer of the households. The study also shows very interesting pictures of households' food insecurity among the service men (including private and govt. jobs). Nearly 39.13 per cent of the households are food insecure and only 20 per cent households are found insecure among the businessmen. According to status of business men is well as compared to other occupation in Harishchandrapur.

\section{Education and Food Insecurity among Muslims}

Literacy and level of education are play important role to improve the socio- economic status of population and also have great role to reduce the level of poverty and standardized the level of living conditions of population (Table4). Level of education also determines the choice of occupation which is directly related to income and educated people always aware to healthy food. According to primary survey, about 81.58 per cent households of Harishchandrapur 2 blocks are food insecure among the uneducated. The study shows very clear picture among different educational level of households and food insecurity. According to study, food insecure is very high among the uneducated population and there is very important parameter, we observed, food insecurity status decreases due to increases the level of education. The primary report present, more than 74 per cent food insecure households are found among the primary educated population where only 14.29 per cent food insecure households found among the higher educated households (Among post graduate and other higher degree pass) When 55.56 per cent households insecure among the middle pass population, followed by high school pass (41.67 per cent) and graduate pass only 16.67 per cent households. Above result clearly indicate that education level reduces food insecurity status of population and also shows that only 48.42 per cent households are found insecure among the educated where 81.5 per cent food insecure among uneducated population.

\section{Food Security and Level of Income among Muslim}

Per capita monthly income is the key factors which determine food insecurity status of households. On the basis of households' income, sampling households is divided into six categories and try to find out the status of households. According to primary survey; about 86.30 per cent food insecure households are found among the income group of less than RS. 3000 when only 16.67 per cent food insecure households are found among the above income group Rs 18000 per month (Table5). Maximum number of food insecure households found among low income groups and minimum number of food insecure found among the higher income groups due to their purchasing power. The food insecure household' decreases due to the increase of income of the household. The second largest number of food insecure households is lies in between income groups Rs 30006000 per month, followed by 7000-10000per month (29.41 per cent), Rs $11000-14000$ per month per household(23.08 per cent) and about 12.50 per cent insecure households found among the income groups of Rs 15000-18000 per month per household. According to study numbers of high income groups are also insecure and low income groups secure due to different causes such as size of family, per capita income, food habit, natural food intake capacity etc. The study is fully prepared on the basis of caloric intake capacity. According to ICMR, $2400 \mathrm{kcal}$ is the standard for living, active and healthy life which is considered for the present study.

\section{Conclusion}

It may be concluded from the above analysis that nearly 63.16 per cent of the households observed had food insecurity all through the year and Per capita food available in calorie decreases with an increase in the household family size. There are also interesting relationship found among the variables likely Per capita calorie 
availability increases with an increases income of the household, education level of the household head, land holding size and occupational of the head, all variables are correlated with the food availability. It also strongly supports the study that there are very strong relations among the determiner of the study.

\section{Suggestion}

- To improve the socio-economic status of the population.

- To provide more monthly income oriented work opportunities.

- To provide more educational facilities and improve the level of education

- Government should be improve the public distribution system and cover all poor people.

- Government have launched various scheme such as jawar Rojgar Yojna, food for work, anganwadi, mid day meal, minimum support programme etc. people have not been fully benefited.

- To organized awareness programme at village level.

- To provides more \& more secondary and tertiary activities among the Muslims

- There is need to adapted such kind of programme which having the permanent solution for reducing the level of food insecurity status.

\section{References}

[1]. Mohammad, A. (1989): Food Production and Food Problem in India, Concept Publication, New Delhi

[2]. Banerjee, B. (1997): Population Explosion, Food Security and Sustainable Development, Geographical Review of India, Vol. 59, No. 1, pp. 1-10

[3]. Bhagat, R. B. (2000): Population Growth, Poverty and Food Grains Supply in India: The Present Trend and Future Prospects, Asian Profile, Vol.23, pp.309-18

[4]. Datta B.B. (1994) Insurgency and economic development in India's North-East, The process of change and development edited by. R.K. Samanta. B.R. Publishing Corporation, New Delhi, pp. 1-38.

[5]. Swaminathan, M.S. (2001): Sustainable Livelihood and Freedom from Hunger, Indian Farming, Vol.51, No.8, pp.6-9.

[6]. Priyadarshini. S, Food Security- A Case Study of Assam. Agriculture, Food Security, Nutrition and health in North-East India edited by Amalesh Banerjee (2006), page 173-183

[7]. Singh R. Production of agriculture crops and its security in Manipur Agriculture, Food Security, Nutrition and health in North-East India edited by Amalesh Banerjee (2006), page 205-212)

[8]. Utpal Kumar Das (2006), Agriculture food ......Food security and the related issues -some reflections on the state of Tripura.

[9]. Bhattacharjee R.P.,Food and Food Security in Arunachal Pradesh. Agriculture, Food Security, Nutrition and health in North-East India edited by Amalesh Banerjee(2006) page 163-168.

[10]. Reutlinger, S. (1987) Food Security and Poverty in Developing Countries in Food Policy: Integrating Supply Distribution and Consumption (eds) Gittinger, J. P., L. Leslie and C. Hoisington, John Hophkins Press London

\section{Study Area Map}

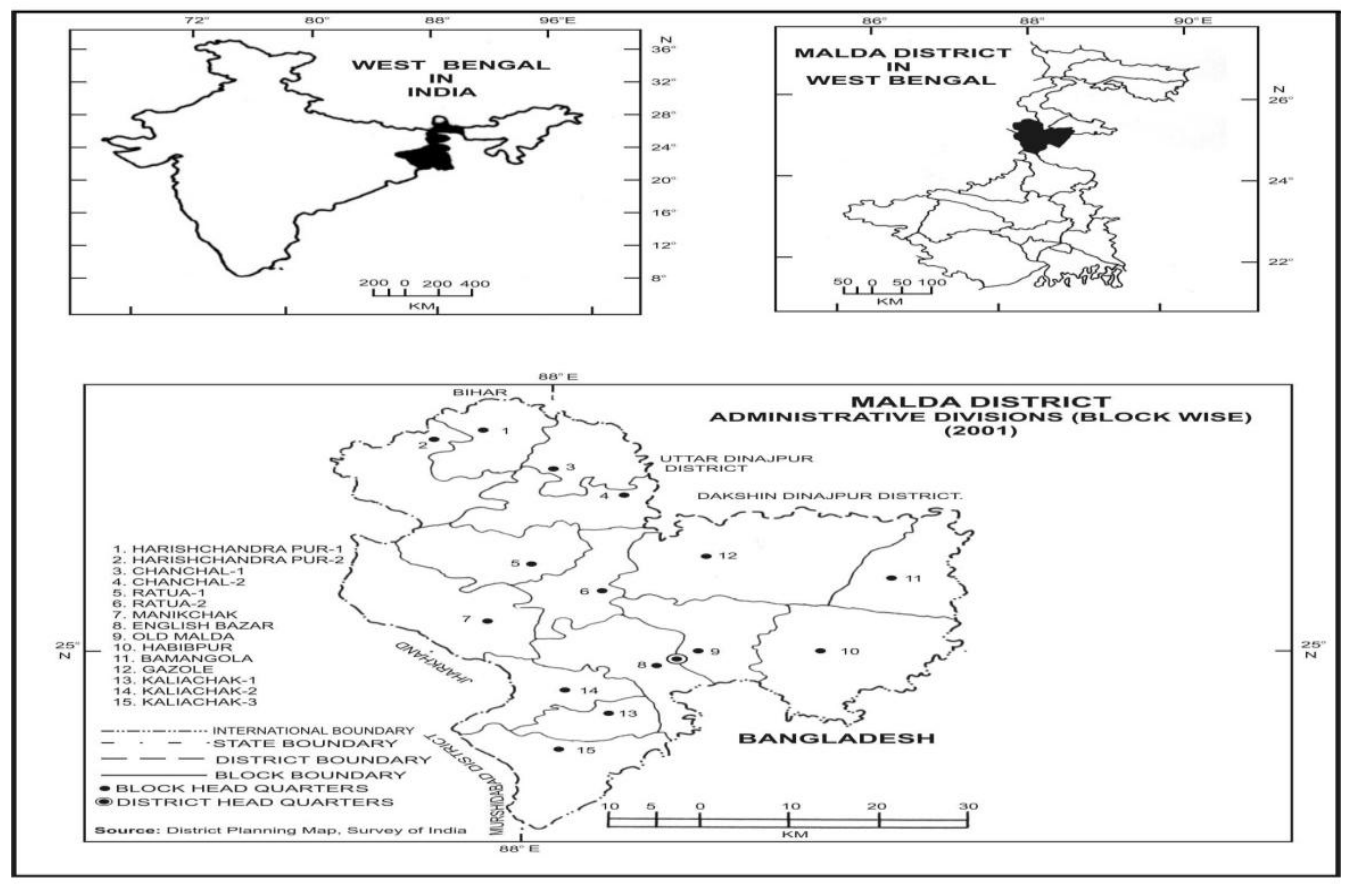


Table1 Shows the Food Insecurity Status of Muslim Households by Size of Family.

\begin{tabular}{|c|c|c|}
\hline Category & Secure (Percentage ) & Insecure (Percentage ) \\
\hline Small family (<5 member(s)) & 61.29 & 38.71 \\
\hline Medium (5-10 members) & 43.86 & 56.14 \\
\hline Large (above 10 members) & 22.89 & 77.11 \\
\hline Total & $\mathbf{3 6 . 8 4}$ & $\mathbf{6 3 . 1 6}$ \\
\hline
\end{tabular}

Source: Field survey 2009

Table2 Shows the Size of Landholding and Food Security and Insecurity Status among the Muslims

\begin{tabular}{|c|c|c|}
\hline Category & Secure in Percentage & Insecure in Percentage \\
\hline Landless & 22.97 & 77.03 \\
\hline$>$ 5bigha & 25.58 & 74.42 \\
\hline 6-10bigha & 58.82 & 41.18 \\
\hline 11-15bigha & 61.90 & 38.10 \\
\hline 16-20bigha & 77.78 & 22.22 \\
\hline$<$ 20bigha & 71.43 & 28.57 \\
\hline Total & $\mathbf{3 6 . 8 4}$ & $\mathbf{6 3 . 1 6}$ \\
\hline
\end{tabular}

Source: Field survey 2009, Note: 1 Bigha $=0.13387$ Hectare

Table3 Shows the Food Insecurity and Security Status among Muslim by Different Occupational Groups

\begin{tabular}{|c|c|c|}
\hline Occupation & $\begin{array}{c}\text { Secure Household in } \\
\text { Percentage }\end{array}$ & Insecure Household in Percentage \\
\hline Farmer & 27.27 & 72.73 \\
\hline Service & 60.87 & 39.13 \\
\hline Business & 80.00 & 20.00 \\
\hline Agriculture lab. & 12.50 & 87.50 \\
\hline Daily laborers & 33.33 & 66.67 \\
\hline Other & 21.43 & 78.57 \\
\hline TOTAL & $\mathbf{3 6 . 8 4}$ & $\mathbf{6 3 . 1 6}$ \\
\hline
\end{tabular}

Source: Field survey 2009.

Table4 Level of Education and Food Status among the Muslim

\begin{tabular}{|l|c|c|}
\hline \multicolumn{1}{|c|}{ Level } & Secure in Percentage & Insecure in Percentage \\
\hline Uneducated & 18.42 & 81.58 \\
\hline Primary & 25.81 & 74.19 \\
\hline Middle & 44.44 & 55.56 \\
\hline Inter Pass $\left(10^{\text {th }}\right)$ & 58.33 & 41.67 \\
\hline $10+2$ & 55.56 & 44.44 \\
\hline
\end{tabular}


Food Insecurity And Indian Muslims

\begin{tabular}{|l|l|l|}
\hline Graduate & 83.33 & 16.67 \\
\hline P. G and Other & 85.71 & 14.29 \\
\hline Total & $\mathbf{3 6 . 8 4}$ & $\mathbf{6 3 . 1 6}$ \\
\hline
\end{tabular}

Source: Field survey 2009.

Table5 Shows Relationship between Food Status and Level of Income

\begin{tabular}{|c|c|c|}
\hline Income group & Secure in Percentage & Insecure in Percentage \\
\hline$>$ Rs 3000 & 13.70 & 86.30 \\
\hline Rs 3000-6000 & 35.19 & 64.81 \\
\hline Rs 7000-10,000 & 70.59 & 29.41 \\
\hline Rs 11,000-14000 & 76.92 & 23.08 \\
\hline Rs 15,000-18000 & 87.50 & 12.50 \\
\hline < Rs 18,000 & 83.33 & 16.67 \\
\hline Total & $\mathbf{3 6 . 8 4}$ & $\mathbf{6 3 . 1 6}$ \\
\hline
\end{tabular}

Source: Field survey 2009. 